\title{
its
}

\section{CMAS / SPAS - Computer scaling and its possible use in the pediatric population}

Authors: Tomáš Žilinčík, Miroslav Novotný

\section{Abstract:}

Compared to conventional paper-pencil testing, computer administration of diagnostic methods has many advantages but also some disadvantages. In the questionnaires, the use of a computer is relatively nonproblematic and psychologists in practice appreciate the time and material efficiency, standardized procedure, and fast and flawless result evaluation. However, in the performance tests (e.g. intelligence tests) it frequently happens that different computer versions of certain classical methods are not equivalent, and thus the results can vary significantly depending on the selected form of testing. The objective of this article is to provide a brief description of the two questionnaires, in which the computerized form of administration seems to be a better choice than classical administration.

CMAS - "Children's Manifest Anxiety Scale" created by Castaneda, McCandless and Palermo was standardized on Czech population by Fischer and Gjuričová in 1974. The questionnaire gives us an approximate estimation of child's anxiety (trait anxiety), controlled by a range of social desirability (i.e. lie scale). In AngloSaxon countries, the revised version of this scale (R-CMAS) is now widely used. This scale however has not been standardized in the Czech Republic yet. Another problem is the fact that the RCMAS test results show significant cross-cultural differences.

SPAS - "Student's Perception of Ability Scale" was created by Boersma and Chapman in 1978; the Czech version was standardized by Matějček and Vágnerová in 1987. This method is used to find out the way the children experience and evaluate their performance and what impression they have of their skills and abilities. Reduced evaluation is typically manifested in anxious children (correlation with CMAS test:

$-0,655$ in boys, $-0,702$ in girls) and in children with specific learning disability.

With regard to standards obsolescence, it is advisable to use both tests as a fast orientation screening in order to be prepared for subsequent interview with the child.

Key words: computer diagnostics, CMAS, SPAS

The dilemma of whether it is better to do the classic pencil-paper testing or rather the computerized form of testing is not new at all - it appears since the 90s, when the home computers became widely spread. Many psychologists consider the computer form of testing to be more efficient form of classical administration that brings many advantages: standardized procedure, time and material efficiency, fast and flawless scoring. We can even take into consideration that the impersonal nature of testing situation reduces the transmission phenomenon on the proband's side. The ergonomics of control is also important, especially in methods with a distinct speed component. E.g. in computer attention tests that are among other things based on measuring proband's reaction time in milliseconds (e.g. IVA PLUS, PASAT etc.) the classic testing using a stopwatch is simply technically impossible (Žilinčík et al., 2012). Even in the questionnaire methods the reaction time on item was significantly reduced because the keystroke (i.e. clicking on a computer mouse or touching the tablet screen) requires less motor activity than writing down a response using pencil and paper. This allows more 
spontaneous answer and proband has fewer tendencies to think about the answer being socially desirable. In addition, children are accustomed to computers and in our experience, when they have to choose between paper-pencil and computer testing, in most cases they choose the latter.

While in the questionnaires the use of computer is relatively trouble-free, in the performance tests, deviation in results often occurs: the deviation depends upon the form of administration. For example, Květon et al. (2003) researched the equivalence of traditional and computerized forms of Intelligence Structure Test (IST -70) and came to a conclusion that particularly in some subtests that work with a visually complex stimulus material (Choosing geometric shapes, Tasks with cube), the probands achieve significantly worse results when the computer administration is used. At the same time, it has proven to be problematic when different computer versions of the original methods are issued as equivalent and are distributed without standards, or more precisely, the standards are taken from the original methods (Nedvěd, 2008).

In this article, we are going to look closely at two questionnaire methods in which the computerized form of administration appears as appropriate: the CMAS (Children's Manifest Anxiety Scale) and SPAS (Student's Perception of Ability Scale) scales. As will be shown later, these methods can be well-combined; both can be used in quick-screening, they correlate with each other and the output can be used for subsequent interview with the child and further exploration of the problem.

\section{The relationship between anxiety, or more precisely, anxiousness and negative self-evaluation}

There are not many researches that deal with the difference in self-approach in anxious and nonanxious children. However, the data available are quite unequivocal. For example, in his research, Matějček (1992) used the same methods we are working with in our article (CMAS and SPAS) and the result of his research confirmed the statistically significant negative correlation between anxiety and decreased selfevaluation in all age groups. Similarly, Jacková (2009) used different method for detecting anxiety (KSAT) but came to similar results: self-approach of school performance is significantly affected by the "examination fever" factor. A certain methodological problem relates to the inconsistence in defining anxiety - the term anxiety, or anxiousness, is defined differently by different authors. It is thus very appropriate to introduce the theoretical concepts that underlie the methods we are referring to. We will also briefly determine the meaning of the terms anxiety and self-approach.

Among the many concepts of origins of anxiety, Spielberg's definition is considered to be one of the most elaborate. Spielberg (1972) distinguishes between anxiety as the current state (state anxiety) and anxiety as a personality characteristic (trait anxiety). These two phenomena are interrelated: the more a person is predisposed to trait anxiety, the more often he/she gets into situations when he/she experiences state anxiety. This in turn enhances his/her tendency to anxiety ever further and a vicious cycle is created. Many authors also suggest that anxiety in not one-dimensional but it results from interaction of several factors. For example, 0 Connor, Loor and Stafford (In Czako, Seeman and Bratsk, 1982) present these four factors: tendency to excessive fears, neurovegetative system instability in situations of growing fear, sleep disorders, and inferiority complex.

The term "self-approach" is one of those terms that most people understand intuitively. Nevertheless, it is difficult to agree on a precise definition. The main notion that is connected to the term "self-approach" is "I". According to Macek (1997, in Výrost and Slaměník), the main feature of "I" is its duality. There is the subjective "I" on one side ("I" as an agent that is aware of itself), and "I" as a subject of an action (in other words, "I" is a subject of its self-examination). The presupposition of self-approach is therefore a certain ability of abstraction and awareness of oneself as an active agent. Other important terms are so called ideal and real "I" and the 
relationship between these two variables. The term "self-approach" comprises not only what a person is like, but also what he/she would like to be or should be. If discrepancy between the real and ideal "I" is too strong, it has a major influence on mental balance. The negative self-approach is thus becoming a source of severe and chronic stress. In this article, we will focus on self-approach of success of elementary school students that forms an important part of global self-approach of children during the school attendance years.

Vágnerová (2001) points out that particularly the following factors affect the development of selfapproach in students:

- experience with one's success or failure

- experience with being evaluated by an authority

- school grades

These factors play an important role especially in young children. With the growing age, the influence of peers is becoming increasingly important. Vymětal (2000) states, that negative response from peers significantly threatens the "I" of the individual. The consequence of the negative response can lead to a strong anxiety of such intensity that the activities in which there is a risk that the child would not succeed in comparison to the peers could be subdued. This situation can lead to drawing off from social relations and development of social skills limitations. Acceptance by classmates, popularity and prestige in the peer group are therefore other factors that greatly contribute to the process of creating a student's self-evaluation.

Some authors (Marsh, 2005) also bring forward the fact that self-approach of school success cannot be taken as a whole but it is necessary to divide it into natural scientific and humanistic components. This concept explains some differences in self-approach of boys and girls. Boys generally feel more confident in natural science while girls in humanities. According to Jacková (2009), differences between the genders are usually wiped out in higher classes of elementary school. Even though girls have slightly higher overall self-approach of school success, the difference is not significant.

\section{Children's Manifested Anxiety Scale (CMAS)}

History: the CMAS self-evaluating method was published in 1956 by Castaneda, McCandless and Palermo. It was created by adjusting a similar scale for adults (MAS). The author of the MAS test, Janet Taylor, did not intend to create a clinical method. The scale was originally designed to classify people according to the level of general drive in the Hull behavioral theory experiments. The MAS scale for adults was also created by selecting certain items describing physiological anxiety symptoms and psychological correlates such as inclination to excessive fear, self-doubt etc. from another test called MMPI. Based on the MAS scale, in 1956 a children's form called CMAS was developed. The CMAS consisted of 42 items for detecting anxiety and 11 items of so called lie scale. The lie scale is inspired by a similar scale in MMPI - it does not detect intentional deceit, it rather detects a tendency to excessive positive self-presentation in the sense of social desirability. The basic normative data were obtained on a sample of 386 children from urban schools; the psychometric properties were satisfactory; test-retest reliability reached level 0.9 on the anxiety scale and level 0.7 on the lie scale.

\section{Czech adjustment of CMAS scale:}

Czech version of the CMAS questionnaire was standardized and adjusted in 1974 by Fischer and Gjurič. Czech version contains a total of 61 items (including 13 items from lie scale). Test items represent a wide range of symptoms. Anxiety (or anxiousness) can manifest itself in different ways: conscious experiencing of anxiety, inferiority or abandonment feelings, somatic problems etc. (Říčan and Krejčírová, 2006). However, the guidebooks that are available do not provide guidance that would facilitate this differentiation. 
CMAS is suitable for children from 9 to 12 years old, but it can be also used for orientation purposes in 13 to 14year-old children because the scale is not substantially dependent on age. For the sake of completeness we can mention the Slovak method standardization that also contains standards that are used in children up to 14 years of age. The questionnaire can be assigned individually or in groups. The administration takes approximately 15 minutes. The child chooses answer yes or no depending on whether he/she agrees or disagrees with the given statement.

From the child's responses, i.e. by quantitative analysis, we can deduce the typical way of experiencing. In a view of the fact, that the standards are quite obsolete Vágnerová (2008) recommends to discern only these areas: area of wide average, area of increased anxiety in zone 7 and area of higher stens (or rather the raw score of 27 or more). The method is well suited for subsequent analysis of items the child agrees with. Matejček recommends that parents also fill in the questionnaire with an instruction: "Answer as you think your child would." Comparing the results of parents and children has a particular diagnostic value, especially if the results differ to a greater extent. The parent may not know the child well in a sense that he/she is unable to empathize and may deny the child's difficulties.

\section{Evaluation of results: CMAS scale}

\begin{tabular}{|l|l|}
\hline Anxiety Score (RS) & 37 \\
\hline Anxiety Score (WS) & 9 \\
\hline
\end{tabular}

\begin{tabular}{|l|c|}
\hline Lie Score (RS) & 2 \\
\hline Lie Score (Occupance) & 33 \\
\hline Lie Score (Supplement) & 67 \\
\hline
\end{tabular}

CMAS versus R-CMAS: in the country of origin and in the world in general, the CMAS is practically not used because in 1978, Reynolds and Richmond developed its revised version: RCMAS. This scale consists of 37 items that are divided into 4 subscales: physiological anxiety, worry/oversensitivity and excessive fears, socially oriented anxiety (social concerns) and lie scale.

1. Physiological anxiety - symptoms of chronic oversensitivity - sleep disorders, restlessness, excessive irritability

2. Worry/oversensitivity, excessive fears: way of responding to external requirements, the subjectively experienced pressure

3. Socially oriented anxiety (social concerns) - excessive concentration on oneself and on comparing with others, constant thinking about the relationships with others, the person feels unloved even though the reality is different

4. Lie scale - scale of social desirability; when compared with CMAS it is subtly revised (8 items)

During the revision, Reynolds and Richmond changed the test name to "What I think and feel", but in literature, the test is better known under the abbreviation RCMAS. The main reasons for the revision were: 
improvement of psychometric criteria, the necessity of adjusting the formulation of items so they would be understandable to little children and to less literate individuals. The question whether RCMAS is a separate test or shortened and improved version of CMAS has not yet been answered. In any case, RCMAS is not standardized to Czech population. The American standards would be inapplicable in our conditions because the results of the test show big cross-cultural differences. According to Boyd (2000), children from Eastern Europe show significantly higher levels of anxiety compared to their US peers. Recently, there was a second revision of the RCMAS scale (RCMAS-2). At the time of writing this article we did not have relevant data in order to be able to assess the contribution of this review.

\section{SPAS - questionnaire of self-approach of school success}

The self-approach scale of school success was created in 1979 by F. J. Boersma and J. W. Chapman. The Czech version was prepared and standardized to Czech population in 1987 by Z Matějček and M. Vágnerová. The last revision took place in 1992. According to Svoboda et al. (2009), the biggest advantage of the method is its simple administration, intelligibility and relatively good validity and reliability. Using this method it is possible to find out in what way children experience and evaluate their school performance and what idea they have about their capabilities and results in school subjects. SPAS contains 6 scales of 8 items each. The items ascertain the overall evaluation of one's abilities, level of confidence, opinion on one's position among the other students, and specifically focused self-assessment in mathematics, reading, grammar and writing skills. The test is designed for children belonging to the age group 10-14 years; the administration takes approximately 10-15 minutes. The questionnaire can be used as one of the methods of the test battery in children that are having some educational problems, i.e. in children that are not prospering in school, children with uneven or fluctuating development of grade pattern, children with specific learning disabilities, children with attention deficit disorders, children who are having problems with adaptation to school, in hyperactive children etc. SPAS can be administered even in children whose problems are seemingly not related to school, but can significantly contribute to learning problems, e.g. in anxious children. Reduced self-evaluation in anxious children is also confirmed by high negative correlation with the CMAS questionnaire $(-0,655$ in boys and $-0,702$ in girls; Matějček, 1992).

The evaluation is easy; the profile of weighted scores serves to assess the subjective evaluation of one's own strengths and weaknesses indicating in which areas the child fells insecure. The diagnostically significant differences are higher than 2 stens. It is appropriate to compare the subjective evaluation of general requirements and the level of self-confidence with the evaluation of specific abilities. Likewise in CMAS, it is also advisable to let the parents fill in the questionnaire in a way they think their child would answer the questions. Comparing the evaluation of partial language skills (reading, grammar and writing skills) can also be very interesting. The acquired results can be used as a foundation for an interview with the child or the parents. The answers that do not correspond to reality (i.e. school performance) can indicate reduced self-evaluation and are thus well suited for this purpose. If self-evaluation does not correspond to the real abilities of the child, it is necessary to find the reason why the child evaluates herself/himself in this way. For example, if the family makes no account of education, the child evaluates his/her results as sufficient even though objectively the results are insufficient. Self-evaluation can also be disproportionate because of immaturity of social intelligence or undeveloped metacognition. Also, children with impaired intelligence are not capable of adequate selfevaluation. Knowing the child's self-evaluation is useful even if it does not correspond to reality because it affects the motivation to learn. Children who consider themselves successful have no need to improve their performance. Conversely, anxious and insecure children that have inadequately low self-evaluation will not be satisfied, even if their school grades are excellent because they will question their future performance. 
The reduced self-evaluation is typical not only for anxious children but also for children with specific learning disabilities. This fact was repeatedly confirmed by researches. Klégrová (1999, in Svoboda) points out that dyslexic children in her study population were able to reach very satisfactory results in reading (more than 70 words per minute) after reeducation. However, their reduced self-evaluation persisted even if there was no longer an objective reason. Fixation of feelings of one's own failure is an important factor that can affect the child's self-confidence even in the future. To this fixation contributes also the fact that children with specific learning disabilities tend to be negatively assessed by their peers and adults. Additionally, the research of Portešová et al. (2014) showed that compared to students without dyslexia, the dyslexic children have worse evaluation in all areas, therefore, their evaluation is worse even in the areas that are not related with their handicap.

The disadvantage of the questionnaire is the outdated formulation of some items. In addition, the child can choose only between two options (yes/no). Some of the areas examined by the questionnaire are in higher classes of elementary school relatively unimportant because they are already fully automated (reading and writing). The remaining 4 areas continue to provide relevant data.

\section{Result evaluation: SPAS scale}
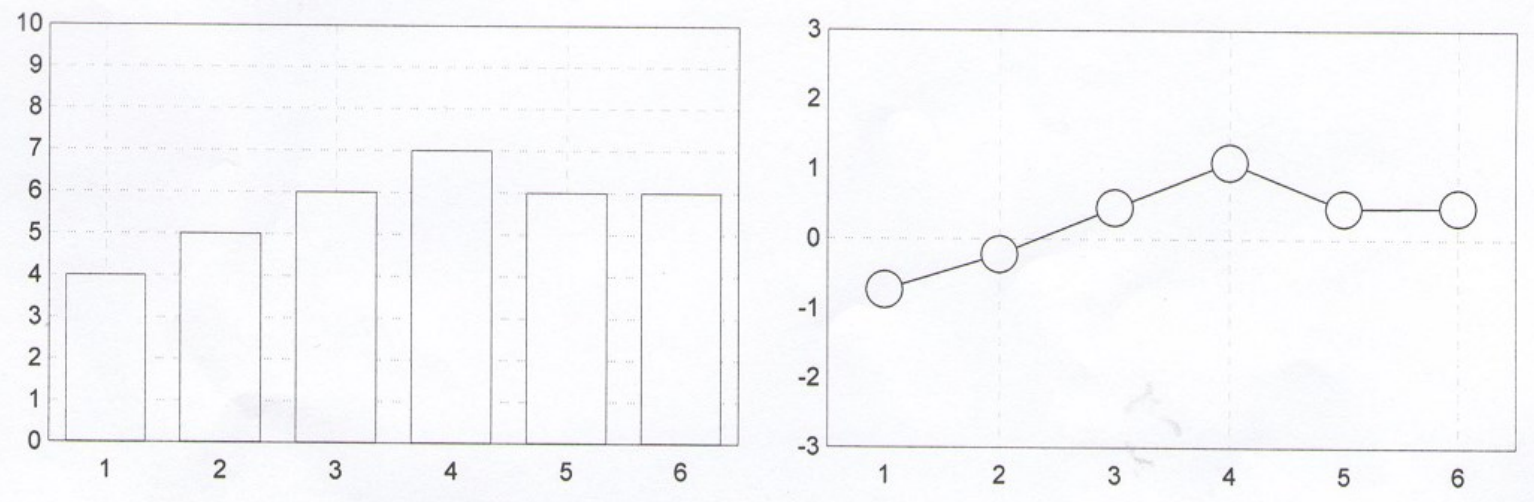

$Y$-axis: stens (average -value)

$X$-axis: numbers of subtests

General skills

Self-confidence

Mathematics

Grammar

Reading

Writing skills
$Y$-axis: z-scores

$X$-axis: numbers of subtests

(same subtests as in the neighbor graph) 


\section{Conclusion:}

The area of psychological assessment was influenced, among other things, by the mass spread of computers in the last 20 years. We often face the dilemma whether we should prefer the classical form of administration (paper-pencil) or choose the computerized form of the original method instead. While in questionnaire, the use of PC brings many advantages in performance tests (especially intelligence tests) the use of computer seems rather problematic as mentioned in the article of Květoň et al. (2003). Our contribution was aimed at two questionnaire methods in which the computer administration appears to be a good choice. The methods we are dealing with are CMAS (Children's Manifest Anxiety Scale) and SPAS (Student's Perception of Ability Scale) questionnaires. These two tests well complement each other because the anxiety is related to reduced self-evaluation. This confirms the mutual and relatively high negative correlation of the tests $(-0,655$ in boys, $-0,722$ in girls). The term "anxiety" comes from the Spielberg's concept (1972) that distinguishes between state anxiety and trait anxiety.

The Children's Manifest Anxiety Scale (CMAS) that was adapted to Czech conditions by Fischer and Gjuričová contains 61 items (including 13 items from lie scale). Considering the obsolescence of standards, Vágnerová (2008) recommends to distinguish only wider standards and area of increased anxiousness (higher than $6^{\text {th }}$ sten). The method is suitable for fast orientation screening and it can be used as a foundation for subsequent interview with the child. In Anglo-Saxon countries, the revised version of the CMAS test is used (RCMAS). Recently, $2^{\text {nd }}$ revision of this test called RCMAS-2 got to the market. These revised versions were not standardized to Czech population; another complication is the fact that the tests show high cross-cultural differences.

The SPAS questionnaire was created in 1978 by Boersma and Chapman; it was modified to Czech conditions by Matějček and Vágnerová in 1987. It maps 6 areas of self-approach of school success (General skills, Self-confidence, Mathematics, Grammar, Reading and Writing skills). The questionnaire can be used as one of the methods of the test battery in children who are having educational problems, i.e. in children that are not prospering in school, children with uneven or fluctuating development of grade pattern, children with specific learning disabilities, children with attention deficit disorders, children who are having problems with adaptation to school, in hyperactive children etc. Reduced self-evaluation is found not only in anxious children but also in students with specific learning disabilities. Likewise, certain differences between genders were found: boys feel more confident in natural science while girls in humanities. These differences are however wiped out by higher age. Test would benefit from revision because formulations of some items seem rather obsolete. Other disadvantages are the close ended questions that require only a yes/no answer, and selfevaluation of Reading and Writing skills in higher classes that lost its meaning (these skills have been already automated).

Both these methods (CMAS and SPAS) are designed for children from 9 (or 10) to 14 years; both tests should be filled also by parents (with the instructions that they should answer in a way they think their child would). Eventual disparities between the parents' and children's evaluation can be diagnostically valuable - for example, parents may lack empathy or deny that the child is having difficulties.

Tomáš Žilinčík, Miroslav Novotný

Cenrum Duševního Zdraví s.r.o.

Dukelská 456, 79001 Jeseník

Private medical center

Psychiatric, psychological, psychotherapeutic center and EEG laboratory

e-mail: tomas.zilincik@yahoo.com 


\section{Literature:}

Boersma, F. J., Chapman, J. W. (1979): Student s perception of ability scale. Manual, University of Alberta, Edmonton, Canada

Boyd, C. P.; Kostanski, M.; Gullone, E.; Ollendick, T. H.; and Shek, D. T. L. (2000) "Prevalence of anxiety and depression in Australian Adolescents; Comparisons with worldwide data", Journal of Genetic Psychology, vol. 161(4), pp. 479-492.

Castaneda, A. M., McCandless, B. R., Palermo, D. S. (1956). The children s form of the manisfest anxiety scale. Child Development, 27 (3), 317-326

Czako, M., Seemanová, M., Bratská, M. (1982): Emócie. Bratislava:SPN

Fischer, J., Gjuričová, Š.(1974): Škála zjevné úzkosti pro děti - CMAS. Bratislava:Psychodiagnostické a didaktické testy

Jacková, A. (2009): Sebepojetí úzkostných dětí a dětí se sklonem $k$ anxiozitě. Diplomová práce. Masarykova univerzita, Brno

Květon, P., Jelínek, D., Vobořil, D., Klimusová, H. (2003): Ekvivalence tradiční a počítačové formy IST-70. Československá Psychologie, 6, 562-572

Macek, P. (1997). Sebesystém, vztah k vlastnímu já. In Výrost, J., Slaměník, I. Sociální psychologie. Praha: ISV, s. 181-209.

Marsh, H. W., Köller, O., Trautwein, U. et al. (2005). Academic Self-Concept, Interest,

Grades, and Standardized Test Scores: Reciprocal Effects Models of Causal Ordering

[Electronic version]. Child Development, 76, 2, s. 397- 416.

http://proquest.umi.com/pqdweb?did=822661011\&sid=5\&Fmt=1\&clientId=45397\&RQT=309\&VName=PQD

Matějček, Z., Vágnerová M. (1992). Dotazník sebepojetí školní úspěšnosti -SPAS. Bratislava: Psychodiagnostika

Nedvěd, J. (2006): Měření pozornosti a souvisejících psychických funkcí pomocí vybraných psychodiagnostických metod. Diplomová práca. Univerzita Palackého, Olomouc

Portešová, Š, Poledňová, I., Kukla, L, Budíková, M. (2014): Longitudinální studie hodnocení schopností spojených se školním výkonem u žáků s dyslexií a bez dyslexie jejich učiteli. Československá psychologie, 3, 222-241

Reynolds, C. R. and Richmond, B. O. (1978) “What I think and Feel: A Revised Measure of Children's Manifest Anxiety”, Journal of Abnormal Psychology, vol. 6(2), pp. 271-280.

Říčan, P., Krejčířová, D. (2006): Dětská klinická psychologie.Praha:Grada

Spielberger, Ch. D. (Ed.). (1972). Anxiety. Current Trend in Theory and Research. New York: Academic Press

Svoboda, M., Krejčířová, D., Vágnerová, M. (2009): Psychodiagnostika dětí a dospívajících. Praha: Portál

Vágnerová, M. (2001). Kognitivní a sociální psychologie ţáka základní školy. Praha: Karolinum 


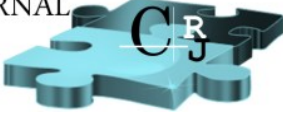

Vágnerová, M., Klégrová, J. (2008): Poradenská psychologická diagnostika dětí a dospívajících. Praha: Karolinum Vymětal, J. a kol. (2000). Speciální psychoterapie. Praha: Psychoanalytické nakladatelství

Žilinčík, T, Novotný, M. (2012): Počítačová diagnostika syndrómu ADHD. Cogmed Remediation Journal, Vol 1, p. 33-38 